\title{
A METHOD TO ESTIMATE THE CONCENTRATION OF ELEMENTS IN SMOKE FROM BURNING VEGETATION GROWING IN CONTAMINATED SOIL (U)
}

Charles E. Murphy Jr.

Westinghouse Savannah River Company Savannah River Site Alken, SC 29808

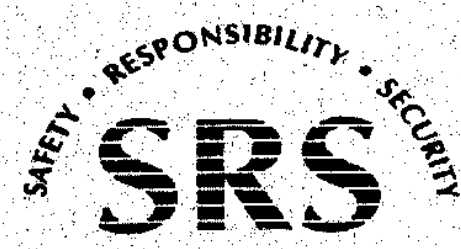


This report was prepared by Westinghouse Savannah River Company (WSRC) for the United States Department of Energy under Contract No. DE-ACO9. 89 SR 18035 and is an account of work performed under that contract. Neither the United States Department of Energy, nor WSRC, nor any of their employees makes any warranty, expressed or implied, or assumes any legal liability or responsibility for the accuracy, completeness, or usefulness, of any information, apparatus, or product or process disclosed herein or represents that its use will not infringe privately owned rights. Reference herein to any specific commercial product, process, or service by trademark, name, manufacturer or otherwise does not necessarily constitute or imply endorsement, recommendation, or favoring of same by WSRC or by the United States Government or any agency thereof. The views and opinions of the authors expressed herein do not necessarily state or reflect those of the United States Government or any agency thereof. 
WSRC-TR-91-109

D.B. Moore, Manager

Authorized Derivative Classifier

\section{A METHOD TO ESTIMATE THE CONCENTRATION OF ELEMENTS IN SMOKE FROM BURNING VEGETATION GROWING IN CONTAMINATED SOIL (U)}

Charles E. Murphy Jr.

Publication Date: March 4, 1991

Approved By: $\quad$ D.B. Moore, Manager

Environmental Sciences Section

Savannah River Laboratory

Westinghouse Savannah River Company

Savannah River Site

Aiken, SC 29808

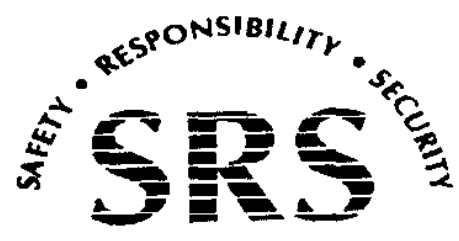

SAVANNAH RIVER SITE

THIS DOCUMENT WAS PREPARED IN CONNECTION WITH WORK UNDER THE U.S. DEPARTMENT OF ENERGY (CONTRACT DE-AC09-89SR18035). 
The Savannah River Site has areas where soil is contaminated with metals and/or radionuclides. Many of these areas are surrounded by native vegetation which is growing adjacent to the area and where the roots have penetrated into the contaminated soil of the area. In some cases vegetation has actually invaded the contaminated area.

Even though the volume of contaminated vegetation is small, there are problems associated with its disposal. Vegetation decomposes quickly after burial and the volume of buried vegetation can decrease. The voids left can lead to subsidence and possible failure of the clay cap constructied over hazardous and/or radioactive waste burial grounds. An alternative to burying the wood is to burn it and bury the ash. However, burning will introduce the contamination in the vegetation into the air where there is potential for inhalation of the contaminants.

A procedure is described to assess the hazard associated with inhalation of contamination from burning of vegetation growing in contaminated soil. The procedure is applied to evaluation of the consequence of burning vegetation grown adjacent to and in the SRL Seepage Basins. The results indicate that burning the vegetation during the day could introduce a level of contaminants to the atmosphere that could cause an exposure greater than the 1 mrem recommended as negligible by the National Council on Radiation Protection and Measurements but lower than the U.S. Department of Energy 100 mrem release guide. A scenario is also investigated where the largest volume of wood, associated with the least contaminated area, is burned. The air concentrations are significantly decreased by this strategy although the total dose commitment due to all radionuclides is still above the 1 mrem dose guide. 
INTRODUCTION .................................................................................................................. 1

DISCUSSION ....................................................................................................... 2 2

Estimating the Concentration in the Vegetation ........................................... 2

Determination of Element Inventories ............................................................... 3

Production of Smoke from Vegetation ....................................................... 4

Dispersion of Smoke in the Atmosphere ........................................................ 5

Effective Source Height .............................................................5

Standard Deviations of Vertical and Horizontal

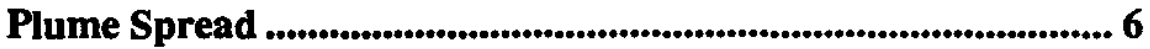

Calculation of Smoke Concentrations from Burning the

Vegetation in the SRL Seepage Basins.......................................... 7

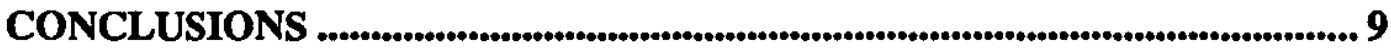

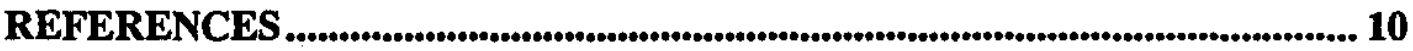


1. Intepolated standard deviation of horizontal plume spread

from interpolation formulas.. . ...........................................................8 8

2. Intepolated standard deviation of vertical plume spread from

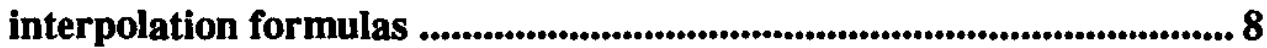

\section{LIST OF TABLES}

1. Vegetation/Soil Concentration Factors. ............................................................... 3

2. Parameters used in Calculation of Effective Release Height. .................................... 6

3. Stability Categories (Turner 1967). ............................................................................ 6

4. Parameters for $\sigma_{z}$ Interpolation Formulas. ..................................................................... 7

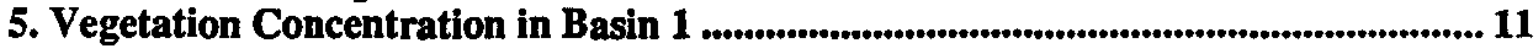

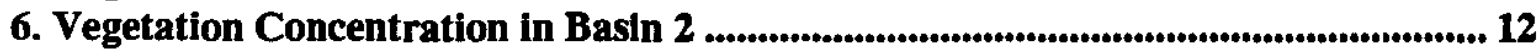

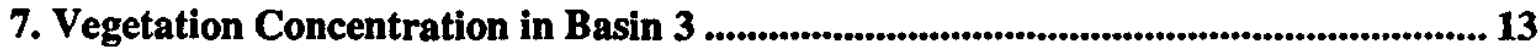

8. Vegetation Concentration in Basin 4 ................................................................. 14

9. Time and Smoke in Percent Smoke in Fire Stages and

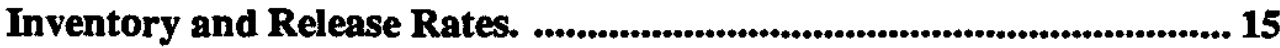

10. Meteorological and Burning Heat Release Conditions ...................................... 16

11. Air Concentration, Initial Stage, Wind Speed 5 m/s ............................................ 17

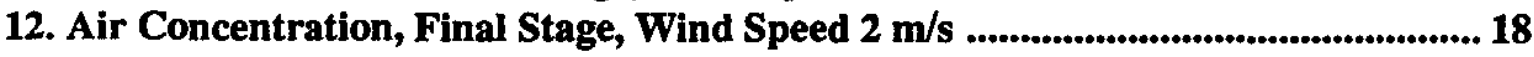

13. Air Concentration, Initial Stage, Wind Speed $5 \mathrm{~m} / \mathrm{s}$, Basin 4 Only..................... 19

14. Air Concentration, Final Stage, Wind Speed $2 \mathrm{~m} / \mathrm{s}$, Basin 4 Only. .................... 20

15. Inhalation Dose from Burning Vegetation (mrem) ................................................ 21 


\title{
A METHOD TO ESTIMATE THE CONCENTRATION OF ELEMENTS IN SMOKE FROM BURNING VEGETATION GROWING IN CONTAMINATED SOIL
}

\author{
C. E. Murphy Jr. \\ Westinghouse Savannah River Company \\ Savannah River Site \\ Aiken, SC 29808
}

\section{INTRODUCTION}

The Savannah River Site has areas where soil is contaminated with metals and/or radionuclides. These sites include seepage basins, ponds and streams downstream from effluent release points. Many of these areas are surrounded by native vegetation which is growing adjacent to the area and where the roots have penetrated into the contaminated soil of the area. In some cases vegetation has invaded the contaminated area.

Even though the volume of contaminated vegetation is small, there are problems associated with its disposal. Vegetation decomposes quickly after burial and the volume of buried vegetation can decrease as much as $70 \%$ after five years ${ }^{1}$. This can lead to subsidence and possible failure of the clay cap over hazardous or radioactive waste burial grounds. A better solution to disposal is to burn the vegetation and dispose almost incompressible ash with the soil and other solids from the contaminated area. However, burning will introduce the contamination in the vegetation into the air where there is the potential for inhalation of contaminants.

A procedure will be described in this document for assessing the hazard associated with inhalation of contamination from burning of vegetation grown on contaminated soil. The procedure will be applied to evaluation of the consequence of burning vegetation grown adjacent to and in the SRL Seepage Basins. The procedure assumes knowledge of the concentration of contaminants in the soil in which the vegetation is growing. Vegetation concentrations are found from 1) the application of known uptake factors from the published literature, 2) the application of site specific uptake factors from previous work or 3) analysis of the vegetation to be burned.

Smoke generation from burning of native vegetation is based on the published literature, as summarized in the U.S. Forest Southern Forestry Smoke Management Guide 2 . Both the timing of fire behavior through the stages of burning and the quantity and gross chemical makeup of the smokemust be specified.

Dispersion is based on the Gaussian plume model using the Pasquill atmospheric stability class as developed in Turner ${ }^{3}$. Plume rise from heat of combustion of the vegetation is determined by the Brigg's method $^{2}$. The dispersion is affected by meteorological conditions through the effect of wind speed and turbulent diffusion on dilution of the plume. The meteorologic conditions used in the calculations are those expected on a day when burning would normally be done; clear, moderate wind, and no precipitation. Calculation are also made for conditions during the following night when the winds and 
turbulent mixing would be expected to be low.

The results of the calculations are the maximum concentration of contaminant in the smoke plume at a number of distances downwind of the fire. This is compared to the limit set by CFR $29^{4}$ and the South Carolina Ambient Air Quality Standards ${ }^{5}$ for metal contaminants. Radioactive Contaminant concentrations are compared to the NCRP, 1 mrem and the DOE, 100 mrem concentration guide.

\section{DISCUSSION}

\section{Estimating the Concentration in the Vegetation}

Plant/soil uptake factors have been used extensively to estimate the transfer of radionuclides and some other contaminants as part of models to determine the effect of contamination on surrounding populations. Compendiums listing the mean and range of these and other transfer factors, (plant to animal, air to animal etc.) have been compiled 6 . The uptake factors between different radionuclides and elements vary greatly. Some heavy metals are rejected by vegetation and the uptake factors are less than 1.0. Other elements are actively concentrated by plants, either as essential elements or chemical analogues for essential elements and may have uptake factor in the range of 100 or more.

However, there are limitations to the use of the uptake factor approach to estimating plant contaminant concentrations. Many of the factors are derived from pot studies were the concentration of contaminant in the volume of soil is well defined and evenly distributed. In field situations the vegetation will remove contaminants from all levels of the soil profile. The removal rate is normally related to root density. In almost all natural stands of vegetation the majority of the root volume is close to the surface. However, the root activity is of ten coupled to water availability which can be greatest below the surface during the drier periods of the year. While, in principle, it is possible to estimate the most active area of root uptake, in practice it is difficult to determine which depth is most active, even if the soil is sampled to provide information on the depth distribution of the contamination. Under these conditions it seems prudent to use the soil concentration at the most contaminated depth.

Uptake factors are further complicated by being a function of soil ( $\mathrm{pH}$, cation exchange capacity) and plant characteristics. Once again, the prudent procedure is to use the greatest uptake factor found in the literature, or at least the greatest for the soil and vegetation type under consideration. This practice of using the greatest known uptake can be relaxed where local uptake factors have been determined for conditions similar to those existing at the site of interest.

Table 1 lists the uptake factors that will be used to calculate the concentration of contaminants in smoke from burning vegetation growing in the SRL Seepage Basins. The source of the uptake factors is listed in the third column and is derived from local uptake factors, if known, or upper values of those found in the literature.

\section{Determination of Element Inventories}


Table 1. Vegetation/Soil Concentration Factors $\left[\left(\mathrm{gm}_{\mathrm{gm}} \mathrm{gry}_{\mathrm{veg}}\right) /\left(\mathrm{gm}_{\mathrm{gm}} \mathrm{gm}_{\mathrm{dry} \text { soli }}\right)\right.$ or $\left.\mathrm{pCi} / \mathrm{pCi}\right]$.

\begin{tabular}{|c|c|c|c|c|c|}
\hline \multirow{2}{*}{ Element } & \multicolumn{2}{|c|}{ Concentration } & \multicolumn{3}{|c|}{ Concentration } \\
\hline & Factor & Reference & Badionuclide & Eactor & Beference \\
\hline Aluminum & 0.004 & 7 & Americium-241 & 0.1 & 6 \\
\hline Arsenic & 1.27 & 8 & Cesium-137 & 3 & 10 \\
\hline Barium & 0.1 & 7 & Cobalt-60 & 1 & 6 \\
\hline Cadmium & 3 & 2 & Curium-243,244 & 0.14 & 6 \\
\hline Chromium & 0.02 & 6 & Plutonium-238 & 0.007 & 6 \\
\hline Copper & 0.3 & 7 & Plutonium-239,240 & 0.007 & 6 \\
\hline Lead & 0.05 & 7 & Strontium-90 & 13 & 10 \\
\hline Manganese & 1 & 6 & Uranium-238 & 0.140 & 6 \\
\hline Magnesium & 1 & 6 & & & \\
\hline Mercury & 0.6 & 9 & & & \\
\hline Nickel & 0.2 & 7 & & & \\
\hline Silver & 1 & 6 & & & \\
\hline Zinc & 0.3 & 7 & & & \\
\hline
\end{tabular}

An estimate of the total vegetative material to be burned is necessary to calculate the total inventory of metals and/or radionuclides. While many tables exist for determining the commercial volume of wood from forest stands it is more difficult to find information on the total mass of material, including branches, bark, and leaves, in vegetation or individual trees. A rough estimate can be made by determining the diameters and heights of each tree or shrub and assuming that the bole is a cone with a dry specific gravity is about 0.5 . Monk ${ }^{11}$ indicated that small pine trees grown at SRS have leaf masses and branch masses that are, respectively $30 \%$ and $20 \%$ of the mass of the boles. These percentages would be expected to vary greatly with the density of the tree in the stand and with the type of tree. A rough estimate of the vegetation mass of the SRL seepage basin was made by inventorying the diameter and height of all the trees and using the conical bole volumes and pine tree mass percentages indicated above.

The inventories of elements and radionuclides were estimated by taking the vegetation concentrations, estimated from the soil concentrations and the concentration factors, and multiplying these by the total mass. Soil/vegetation concentration ratios do vary with the type of vegetation structures analyzed and it is possible to use individual concentration factors for leaves, branches and stems. However, the range of concentration factors between different parts of plants of the same species is often as large as the range between different species; therefore, the concentration factor normally used, when measurements are not available, are the highest found in the literature for any particular element. In the case of the SRL seepage basins, the mass of trees surrounding an individual basin was calculated from the highest applicable concentration factor and the soil concentration in a particular basin.

\section{Production of Smoke from Vegetation}


The following description of the burning process is taken from the Southern Forestry Smoke Management Guide ${ }^{2}$. The generation of smoke from the burning of vegetation occurs in two stages. First the components of the vegetation are decomposed, by pyrolysis, at high temperature. Pyrolysis is an endothermic reaction requiring heat from the fire. The vegetation is decomposed into char, vapors, high molecular weight hydrocarbons, and particles.

Pyrolysis is followed by the combustion stage where the pyrolysate vapors escaping the surface of the vegetation are rapidly oxidized. Combustion is an exothermic process which supplies heat to the fire.

Fire behavior in the burning of woody fuels can be categorized into three phases. The initial phase is the pre-ignition phase where the process of pyrolysis is dominant as material is heated from the adjacent fire. This is followed by the flaming phase where the pyrolysis products are ignited and are rapidly oxidized. The products of the flame zone are primarily carbon dioxide and water vapor. Pyrolysis products which do not pass through the flame zone or are only partly oxidized as they pass through the flame zone may remain as gasses or condense in the form of small, tarry, liquid droplets and solid soot particles. These materials and ash suspended by the turbulent air flowing through in the fire make up the smoke leaving the fire.

The flaming phase is followed by the glowing phase where the char left from the flaming phase is oxidized, producing a characteristic glow. This will continue as long as temperatures remain high enough and until only small amounts of noncombustible minerals remain as gray ash. In the glowing phase fuel particles and pyrolysis products are not always consumed. As the fire burns out the glowing phase will predominate and result in a large production of smoke. In this stage of the fire, the air movement through the fire is not as rapid and the majority of the ash is not suspended in the air. Therefore, in spite of the larger quanitity of sooty smoke produced, the fraction of noncombustible, metal-containing ash entering the air is less during this stage.

The history of an individual fire can often be condensed into two phases. The first phase includes the first two phases described above and is characterized by convective uplift of the smoke by the heat of the fire. The second phase is the smoldering phase where the convective uplift is negligible. It is necessary to estimate smoke dispersal separately for these two phases.

The metals and radionuclides in the vegetation will be involved in all of the processes described above. If these materials are part of the structural material of the vegetation or in solution in the vegetation moisture, they may be pyrolyzed or volatilized in the fire and become airborne. Even if an element is oxidized to a refractory form which is not easily volatilized, the non-flammable ash may be suspended in the air with the other smoke constituents during the convective phase of the fire. During the convective phase most of the material in the vegetation would be expected to enter the atmosphere and be carried downwind. Much of the particulate produced from a fire is in the range of particle sizes that are inhaled into the lungs. During the smoldering phase of the fire much of the refractory elemental compounds would remain in the ash and not enter the atmosphere. Even though this fire phase produces more smoke in proportion to the fuel burned, that smoke will contain a smaller fraction of the refractory metal and 
radionuclide materials.

Unfortunately no information is available about what fraction of the ash is left after burning vegetation. Even though it is obvious to anyone who has witnessed the burning of a wood fire that there is considerable ash left on the ground after the fire, the only assumption that can be justified in calculations is the most conservative assumption that all of the material will enter the atmosphere and be available for inhalation from the smoke.

\section{Dispersion of Smoke in the Atmosphere}

The Gaussian model of atmospheric dispersion has been shown to adequately describe the transport of air pollutants under most atmospheric conditions. It is the preferred method for estimation of the effect of atmospheric releases for most assessment documents. The form of this model used in this procedure is the one proposed by Pasquill as described in Turner. ${ }^{3}$. The model is used to compute the highest (centerline) concentration, $\chi$, at the ground at a given distance downwind of the source. The equation is:

$$
\chi=\frac{Q}{\pi \sigma_{y} \sigma_{z} u} \exp \left[-\frac{1}{2}\left(\frac{H}{\sigma_{z}}\right)^{2}\right]
$$

The inputs for the equation are the source strength, $Q$, wind speed, $u$, the effective height of the source, $H$, the standard deviation of the horizontal spread of the plume, $\sigma_{y}$, and the standard deviation of the vertical spread of the plume, $\sigma_{z}$. The desired wind speed is the mean wind speed at the height of the plume.

\section{Effective Source Height}

In the convective stage of burning, the effective source height is above the actual source at the surface because of the buoyant effect of the heat of the fire on the plume. The Brigg's plume rise formula has been modified for use in determining the effective source height of open fires ${ }^{2}$. The formula is

$$
\mathrm{H}=\alpha \mathrm{Q}_{\mathrm{H}}{ }^{\mathrm{n}} \mathbf{u}^{\mathbf{m}}
$$

where $Q_{H}$ is the total rate of heat release from the fire, $u$ is the wind speed, and the parameter a, $n$, and $\mathrm{m}$ are a function of the atmospheric stability and the rate of heat release (Table 2).

The heat of combustion of dry wood averages around $4.8 \times 10^{8}$ calories per metric ton. The average of fuels found in forest fires is about $3.5 \times 10^{8}$ calories per metric ton. The effective source height can be calculated knowing the mass of fuel to be burned and the time over which the fire will occur. The time of combustion is, to some extent controllable by the placement and addition of fuel to the fire. Calculations made later in this document assume that the fire will be designed to burn within six hours during the daylight period. The smoldering phase may continue into the following night. If the fire burns more rapidly than expected the amount of any material in the smoke will increase: however, the smoke concentration at the ground may actually decrease because of the increase in effective source height 
Table 2. Parameters used in Calculation of Effective Release Height

\begin{tabular}{lllll} 
& & \multicolumn{3}{c}{ Stability Class } \\
\cline { 3 - 5 } Parameter & $\mathbf{Q}_{\mathbf{H}}(\mathrm{cal} / \mathrm{s})$ & $\mathbf{A}-\mathbf{D}$ & $\mathbf{E}$ & $\mathbf{E}$ \\
$\alpha$ & $<1.4 \mathrm{e} 6$ & 0.0101 & 0.917 & 0.761 \\
$\alpha$ & $>1.4 \mathrm{e} 6$ & 0.0847 & 0.917 & 0.761 \\
$\mathrm{n}$ & $<1.4 \mathrm{e} 6$ & $3 / 4$ & $1 / 3$ & $1 / 3$ \\
$\mathrm{n}$ & $>1.4 \mathrm{e} 6$ & $3 / 5$ & $1 / 3$ & $1 / 3$ \\
$\mathrm{~m}$ & all & -1 & $-1 / 3$ & $-1 / 3$
\end{tabular}

caused by the additional heat from the fire.

\section{Standard Deviations of Vertical and Horizontal Plume Spread}

The standard deviation of horizontal plume spread is taken from the graphs in Turner ${ }^{3}$. An interpolation formula has been developed for ease of calculation.

$$
\sigma_{y}=105 \exp \left[-0.37\left(S_{c}-3\right)\right] x^{0.89}
$$

In this formula the numeric value of the stability class, $S_{c}$, corresponds with a one for class $A$ through six for class F. The selection of class can be made from Table 3, copied from Turner. In the SRL seepage basin calculations a class $B$ is used to assess the dispersion for daylight periods and a class $D$ for night.

The standard deviation of vertical plume spread is also calculated from an interpolation formula.

$$
\sigma_{z}=\left\{7.1 \exp \left[-0.36\left(S_{c}-3\right)\right](x / 0.1)^{0.92}\right\}\{\exp [b \times \subsetneq+a\}\{1-a\}
$$

Table 4 provides values of the parameters of the formula for each of the stability classes. Note that extrapolations of class A diffusion are tentative as shown by the broken line in Turner. Figures 1 and

Table 3. Stability Categories (Turner 1967)

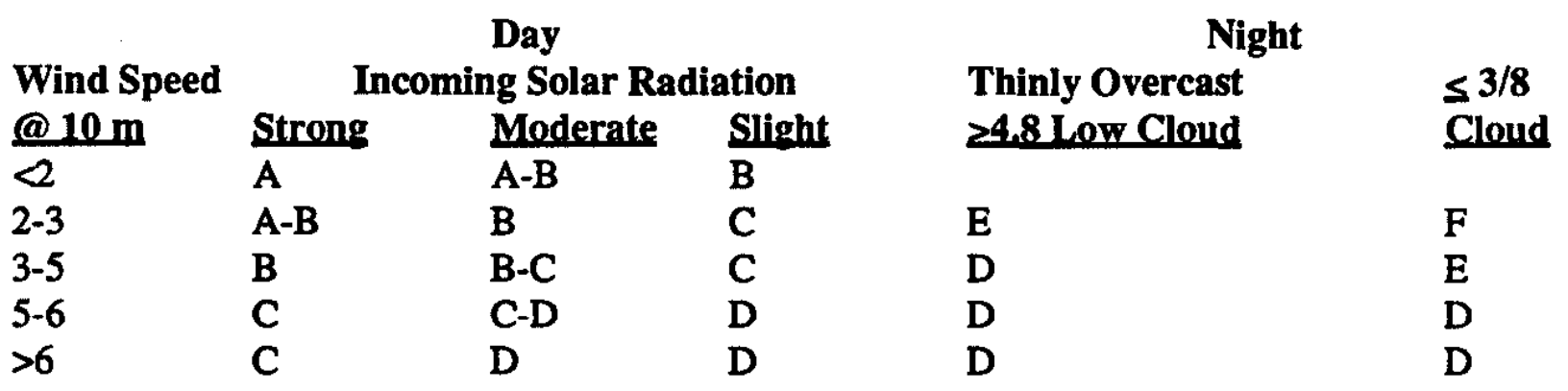


2 show the variation in the standard deviations as calculated from the formulas.

\section{Calculation of Smoke Concentrations from Burning the Vegetation in the SRL Seepage Basins}

The results of calculation of the concentration of elements and radionuclides of concern are provided in Tables 5-12. Tables 5-8 show the determination of element and radionuclide inventories from the vegetation growing around each of the seepage basins. The soil concentrations are the average concentration of the most contaminated depth of soil for each basin. Table 9 summarizes the inventory for all four basins. As the summary suggests, the inventory in the vegetation is small.

Table 9 shows the burning times used for each stage of the fire and the resulting release rates. This information is used with the meteorological input, also summarized in Table 10, to calculate the air concentrations downwind of the fire at distances of 100 meters, 1 kilometer, 3 kilometers and 10 kilometers. The distances were picked because of the proximity of buildings at SRS and the Site boundary. The results are shown for two hypothetical cases. Table 11 shows the concentrations for a daytime burn under fully developed convective conditions (class B). Table 12 shows the concentrations for a night time period of smoldering under stable conditions and no convective uplift from the fire (class D).

Two standards are shown for judging the relevance of the concentrations for each of the elements, the 8-hour time weighted average (TWA) limit for breathing 4 and the South Carolina Ambient Air Quality Standard ${ }^{5}$ (where they exist). Two other standards are shown for the radionuclide concentrations. The radionuclide standards are based on the air concentration that would cause an equivalent dose commitment of 1 or 100 mrem from inhalation of the radionuclide. The $1 \mathrm{mrem}$ dose is based on the NCRP position that dose of less than $1 \mathrm{mrem}$ is of no practical health concern. The 100 mrem dose is the DOE occupational limit.

\section{CONCLUSIONS}

Table 4. Parameters for $\sigma_{z}$ Interpolation Formula

$\begin{array}{lrrrrrr}\text { Parameter } & \mathbf{A} & \mathbf{B} & \mathbf{C} & \mathbf{D} & \mathbf{E} & \mathbf{E} \\ \text { b } & -1.54 & -0.33 & 0 & 0.27 & 0.30 & 0.40 \\ \text { c } & 0.25 & 0.37 & 1 & 0.650 & 0.60 & 0.55 \\ \text { a } & 0.20 & 0.20 & 0.10 & 0.120 & 0.085 & 0.06\end{array}$




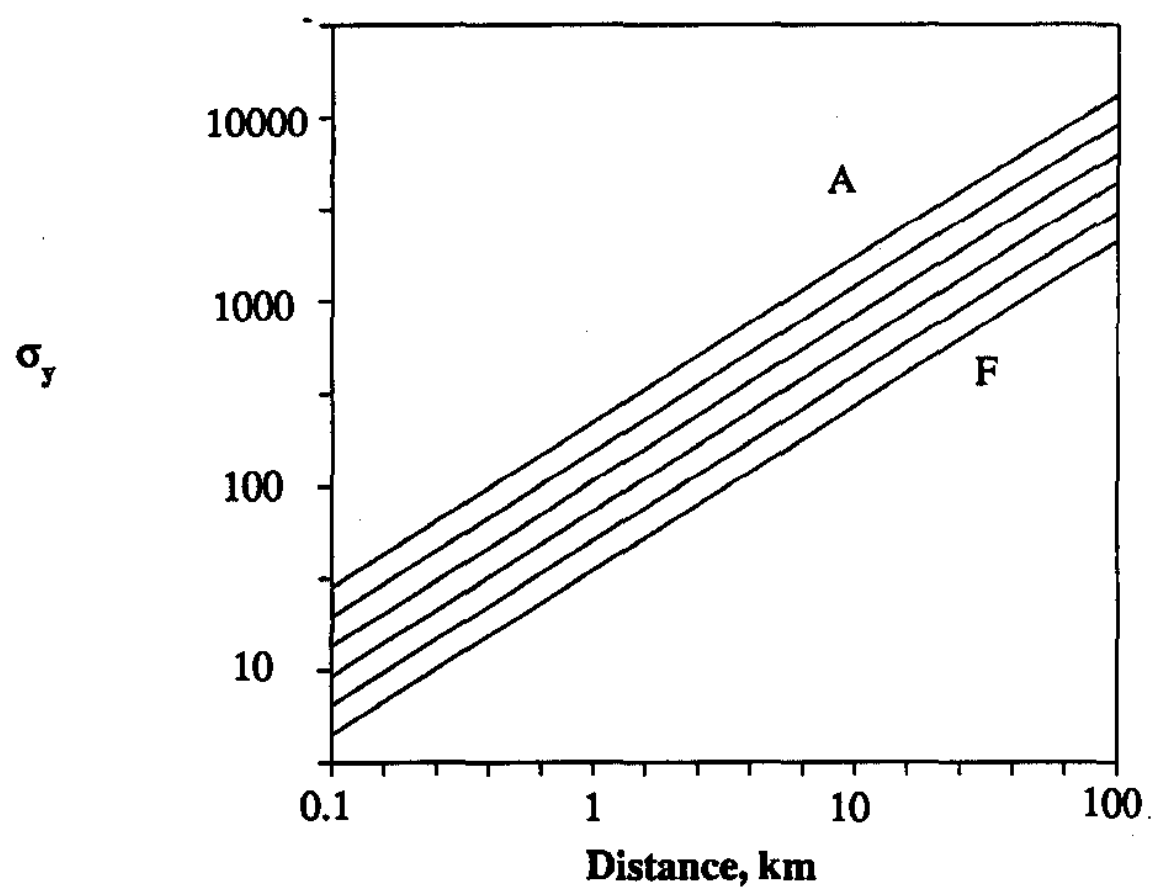

Figure 1. Intepolated standard deviation of horizontal plume spread from interpolation formulas.

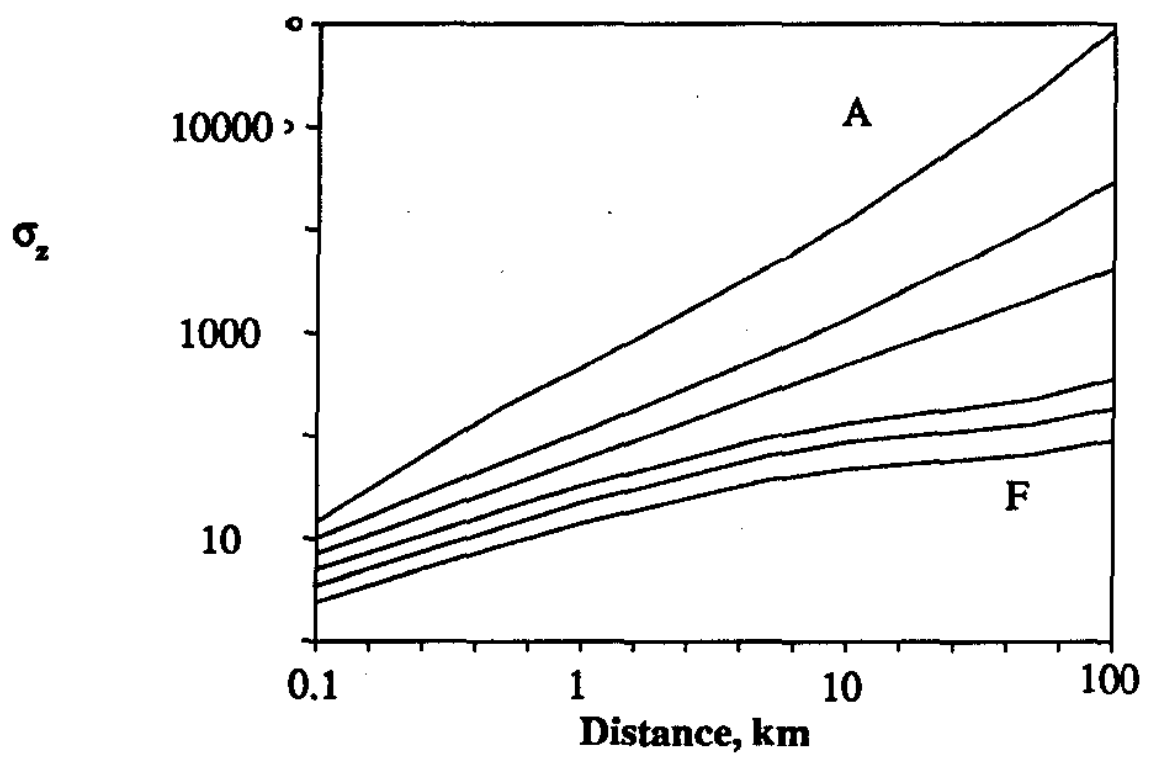

Figure 2. Intepolated standard deviation of vertical plume spread from interpolation formulas. 


\section{Conclusions}

As shown in Tables 11 and 12, no metal contaminant has an air concentration within 100 times the TWA or the South Carolina Ambient Air Quality Standard. However, the concentration of curium-243,244 is above the $1 \mathrm{mrem}$ while still below the $100 \mathrm{mrem}$ guide for the daytime burning conditions. The total dose commitment from all radionuclides during the daytime burning is about 5 mrem (Table 15). Conditions are somewhat worse at night. In addition to the curium dose, which is over three times greater than the daytime dose, the dose due to americium-244 is greater than the $1 \mathrm{mrem}$ guide and the dose due to strontium-90 is close to the $1 \mathrm{mrem}$ level. The total dose from a fire which consumes $90 \%$ of the fuel during six hours of the day and the remaining $10 \%$ of the fuel over the next 12 hour night is $23 \mathrm{mrem}$. This suggests that it would be possible to significanly reduce the dose by putting out the fire at the end of the day when the majority of the volume reduction has taken place.

It is possible to use this procedure to look at other burning scenarios that could decrease the potential airbourne radioactivity to acceptable levels. One possibility would be to burn only the vegetation around basin 4 . The soil concentration of radionuclides is much less in basin 4 than in the other three basins but the mass of vegetation is over half the total mass. This would significantly reduce the volume of material to be put under the seepage basin.

Tables 13 and 14 show the results of calculating the concentrations for burning only basin 4 vegetation. The results indicate a reduction of in the total dose from $23 \mathrm{mrem}$ to about $3 \mathrm{mrem}$. During the daytime the individual dose of all radionuclides are below the the $1 \mathrm{mrem}$ guide although the total daytime dose, largely caused by curium, is slightly greater than $1 \mathrm{mrem}$. The dose of curium remains above the $1 \mathrm{mrem}$ level for the night conditions.

These results suggest that the impact of daytime burning is not great and can be further reduced by burning only the vegetation from around basin 4 . The night doses are also not large but can not be treated as negligible as defined by the NCRP. One strategy would be to extinguish the fire when it reaches the smoldering stage. Most of the volume reduction will be accomplished at this point. 


\section{REFERENCES}

1. Gholz, H.L., L.M. Krazynski and B.G. Volk. "Disappearance and Compressibility of Buried Pine Wood in a Warm Temperate Soil Environment." Ecol. Appl. 1:85-88 (1990)

2. "Southern Forestry Smoke Management Guide." USDA-Forest Service, Southern Forest Fire Laboratory, Macon, GA 140 pp (1976).

3. Turner, D.B. 1967. "Workbook of Atmospheric Dispersion Estimates." USDHEW, National Center for Air Pollution Control, Cincinnati, Ohio 84 pp. (1967).

4. Code of Federal Regulations 29, part 1910, National Archives and Records Administration, Washingtion, DC (revised July 1, 1989)

5. South Carolina Ambient Air Quality Standards, State AirLaws, The Bureau of National Affairs, Inc., Washington, DC (revised May 25, 1990).

6. Coughtrey, P.J. and M.C. Thorne. "Radionuclide Distribution and Transport in Terrestrial and Aquatic Ecosystems, A Critical Review of Data." A.A. Balkema, Rotterdam, 6 volumes (1983)

7. Lorenz, R. "Results from the Sampling and Analysis Program for Vegetation Located within the MArea HWMF." DPSP-88-1181, E.I. du Pont de Nemours and Co., Inc., Savannah River Plant, Aiken, SC 22 pp. (1988).

8. National Research Council. "Arsenic, Medical and Biological Effect of Environmental Pollutants". National Academy of Sciences, Washington, DC, 332 pp. (1977)

9. Adriano, D.C. "Trace Elements in the Terrestrial Environment." Springer-Verlag, Berlin, p. 314 (1986)

10. Gay, D.L. "Burial Ground Uptake Studies - Surface Contamination." DPST-82-1072, E.I. du Pont de Nemours and Co., Inc., Savannah River Laboratory, Aiken, SC, 24 pp. (1982).

11. Monk, C.D. 1966. "Root-shoot Dry Weights in Loblolly Pine." Bot. Gaz. 127: 246-248 (1966). 
Table 5. Vegetation Concentration in Basin 1

Vegetation Mass (dry) $\quad 3.5$ metric tons

Element Concentrations in SRL Seepage Basin Vegetation

Element

Measured* Soil

Concentration

1.

10676.0

3.3

24.5

2.6

136.0

49.4

55.0

67.6

103.6

16.9

64.4

16.5

77.2
Concentration

Eactor
Estimated

Vegetation

Concentration

ug/gm

42.7

4.2

2.5

7.8

2.7

14.8

2.8

67.6

103.6

1.0

12.9

16.5

23.2
Total

Element

kg

Silver

Zinc

1.000

0.300

$\frac{\mathrm{nCi} / \mathrm{gm}}{26}$

1086

0.100

nCi/gm

curies

Americium-241

Cesium-137

Cobalt 60

Curium-243,244

Plutonium-238

Plutonium-239,240

Strontium-90

Uranium-238

5

3.000

1.000

400

0.140

17

0.007

76

0.007

141

13.000

17

2.590
3258.000
4.900
56.000
0.118
0.529
1833.000
2.338

9.06E-06

$1.14 \mathrm{E}-02$

1.71E-05

1.96E-04

4.11E-07

$1.85 \mathrm{E}-06$

6.41E-03

8.18E-06

* Mean concentration of the most contaminated depth measured, usually the surface six inches. 
Table 6. Vegetation Concentration in Basin 2

Vegetation Mass (dry) 3 metric ton

Element Concentrations in SRL Seepage Basin Vegetation

Element

Measured* Soil
Concentration
yg/gm

\begin{tabular}{lll} 
& $\begin{array}{l}\text { Estimated } \\
\text { Vegetation } \\
\text { Concentration }\end{array}$ & Total \\
Element \\
Concentration \\
Eactor & $\begin{array}{l}\text { Ho/gm } \\
\text { kg }\end{array}$ & \\
\hline
\end{tabular}

$\begin{array}{lrrrr}\text { Aluminum } & 11718.0 & 0.004 & 46.9 & 0.117 \\ \text { Arsenic } & 6.7 & 1.270 & 8.5 & 0.021 \\ \text { Barium } & 51.2 & 0.100 & 5.1 & 0.013 \\ \text { Cadmium } & 6.8 & 3.000 & 20.4 & 0.051 \\ \text { Chromium } & 140.2 & 0.020 & 2.8 & 0.007 \\ \text { Copper } & 90.9 & 0.300 & 27.3 & 0.068 \\ \text { Lead } & 84.1 & 0.050 & 4.2 & 0.011 \\ \text { Manganese } & 209.6 & 1.000 & 209.6 & 0.524 \\ \text { Magnesium } & 245.5 & 1.000 & 245.5 & 0.614 \\ \text { Mercury } & 21.3 & 0.060 & 1.3 & 0.003 \\ \text { Nickel } & 89.5 & 0.200 & 17.9 & 0.045 \\ \text { Silver } & 9.1 & 1.000 & 9.1 & 0.023 \\ \text { Zinc } & 151.8 & 0.300 & 45.5 & 0.114\end{array}$

Radionuclide

Americium-241

pCi/gm

Cesium-137

Cobalt -60

Curium-243,244

Plutonium-238

Plutonium-239,240

Strontium-90

Uranium-238

$\begin{array}{rr}31 & 0.100 \\ 1448 & 3.000 \\ 82 & 1.000 \\ 433 & 0.140 \\ 56 & 0.007 \\ 181 & 0.007 \\ 356 & 13.000 \\ 91 & 0.140\end{array}$

DCi/gm
3.080
4344.000
82.000
60.620
0.392
1.267
4628.000
12.796

curies

7.70E-06

$1.08 \mathrm{E}-02$

2.05E-04

1.51E-04

$9.80 \mathrm{E}-07$

3.16E-06

$1.15 \mathrm{E}-02$

3.19E-05

* Mean concentration of the most contaminated depth measured, usually the surface six inches. 
Table 7. Vegetation Concentration in Basin 3

Vegetation Mass (dry)

1 metric ton

Element Concentrations in SRL Seepage Basin Vegetation

Element

Measured* Soil
Concentration
ng/gm

\begin{tabular}{lll} 
& $\begin{array}{l}\text { Estimated } \\
\text { Vegetation } \\
\text { Concentration }\end{array}$ & $\begin{array}{l}\text { Total } \\
\text { Element }\end{array}$ \\
Concentration & $\begin{array}{l}\text { vactom } \\
\text { Eactor }\end{array}$ & $\mathrm{kg}$ \\
\hline
\end{tabular}

$\begin{array}{lrlrl}\text { Aluminum } & 8023.0 & 0.004 & 32.1 & 0.016 \\ \text { Arsenic } & 5.4 & 1.270 & 6.9 & 0.003 \\ \text { Barium } & 6.5 & 0.100 & 0.7 & 0.000 \\ \text { Cadmium } & 0.6 & 3.000 & 1.9 & 0.001 \\ \text { Chromium } & 24.6 & 0.020 & 0.5 & 0.000 \\ \text { Copper } & 9.6 & 0.300 & 2.9 & 0.001 \\ \text { Lead } & 8.0 & 0.050 & 0.4 & 0.000 \\ \text { Manganese } & 32.1 & 1.000 & 32.1 & 0.016 \\ \text { Magnesium } & 33.8 & 1.000 & 33.8 & 0.017 \\ \text { Mercury } & 1.5 & 0.060 & 0.1 & 0.000 \\ \text { Nickel } & 11.2 & 0.200 & 2.2 & 0.001 \\ \text { Silver } & 0.2 & 1.000 & 0.2 & 0.000 \\ \text { Zinc } & 24.0 & 0.300 & 7.2 & 0.004\end{array}$

Radionuclide

Americium-241

nCi/am

Cesium-137

Cobalt -60

Curium-243,244

Plutonium-238

Plutonium-239,240

Strontium-90

Uranium-238

$\begin{array}{rr}1 & 0.100 \\ 559 & 3.000 \\ 10 & 1.000 \\ 35 & 0.140 \\ 2 & 0.007 \\ 1 & 0.007 \\ 1435 & 13.000 \\ 16 & 0.140\end{array}$

nCi/gm

curies

0.130

6.50E-08

1677.000

8.38E-04

10.400

$5.20 \mathrm{E}-06$

4.900

2.45E-06

0.016

8.05E-09

3.85E-09

9.32E-03

18655.000

$1.09 \mathrm{E}-06$

* Mean concentration of the most contaminated depth measured, usually the surface six inches. 
Table 8. Vegetation Concentration in Basin 4

Vegetation Mass (dry) 11 metric ton

Element Concentrations in SRL Seepage Basin Vegetation

Element

\begin{tabular}{|c|c|c|c|}
\hline & & & Total \\
\hline oncentration & $\begin{array}{l}\text { Concentration } \\
\text { Eactor }\end{array}$ & $\begin{array}{l}\text { Concentration } \\
\mu \mathrm{g} / \mathrm{gm}\end{array}$ & $\mathbf{k g}$ \\
\hline
\end{tabular}

$\begin{array}{lrrrr}\text { Aluminum } & 11602.0 & 0.004 & 46.4 & 0.510 \\ \text { Arsenic } & 8.1 & 1.270 & 10.2 & 0.112 \\ \text { Barium } & 7.9 & 0.100 & 0.8 & 0.009 \\ \text { Cadmium } & 0.4 & 3.000 & 1.2 & 0.013 \\ \text { Chromium } & 30.7 & 0.020 & 0.6 & 0.007 \\ \text { Copper } & 10.2 & 0.300 & 3.1 & 0.034 \\ \text { Lead } & 4.9 & 0.050 & 0.2 & 0.003 \\ \text { Manganese } & 24.6 & 1.000 & 24.6 & 0.271 \\ \text { Magnesium } & 10.7 & 1.000 & 10.7 & 0.118 \\ \text { Mercury } & 0.4 & 0.060 & 0.0 & 0.000 \\ \text { Nickel } & 6.8 & 0.200 & 1.4 & 0.015 \\ \text { Silver } & 0.3 & 1.000 & 0.3 & 0.003 \\ \text { Zinc } & 23.5 & 0.300 & 7.1 & 0.078\end{array}$

Radionuclide

Americium-241

Cesium-137

Cobalt -60

Curium-243,244

Plutonium-238

Plutonium-239,240

Strontium-90

nCi/gm

0.100

nCi/gm

curies

4

3.000

0.357

3.92E-06

158

1.000

474.000

5.21E-03

2

1.850

2.03E-05

33

0.140

4.620

5.08E-05

$1 \quad 0.007$

0.007

5.00E-08

1

0.005

4.38E-08

$13 \quad 13.000$

0.004

$1.88 \mathrm{E}-03$

Uranium-238

$5 \quad 0.140$

171.600

8.31E-06

* Mean concentration of the most contaminated depth measured, usually the surface six inches. 
Table 9. Time and Smoke in Percent Smoke in Fire Stages and Inventory and Release Rates.

Fire

Stages

Initial

Final

\begin{tabular}{crc}
$\begin{array}{c}\% \\
\text { Burned }\end{array}$ & $\begin{array}{c}\% \\
\text { Smoke }\end{array}$ & $\begin{array}{l}\text { Time in } \\
\text { Stage, min }\end{array}$ \\
\hline 90 & 2 & 360 \\
10 & 9 & 1080
\end{tabular}

Inventory and Release Rates

Element

Aluminum

Arsenic

Barium

Cadmium

Chromium

Copper

Lead

Manganese

Magnesium

Mercury

Nickel

Silver

Zinc

Radionuclide

Americium-241

Cesium-137

Cobalt -60

Curium-243,244

Plutonium-238

Plutonium-239,240

Strontium-90

Uranium-238

\begin{tabular}{lcc} 
Inventory & \multicolumn{2}{c}{ Release Rate } \\
\cline { 2 - 3 } kg & $\begin{array}{c}\text { Initial } \\
\text { gm/s }\end{array}$ & $\begin{array}{c}\text { Final } \\
\text { gm/s }\end{array}$ \\
0.79 & $3.30 \mathrm{E}-02$ & $1.22 \mathrm{E}-03$ \\
0.15 & $6.32 \mathrm{E}-03$ & $2.34 \mathrm{E}-04$ \\
0.03 & $1.26 \mathrm{E}-03$ & $4.69 \mathrm{E}-05$ \\
0.09 & $3.85 \mathrm{E}-03$ & $1.42 \mathrm{E}-04$ \\
0.02 & $9.80 \mathrm{E}-04$ & $3.63 \mathrm{E}-05$ \\
0.16 & $6.46 \mathrm{E}-03$ & $2.39 \mathrm{E}-04$ \\
0.02 & $9.59 \mathrm{E}-04$ & $3.55 \mathrm{E}-05$ \\
1.05 & $4.36 \mathrm{E}-02$ & $1.61 \mathrm{E}-03$ \\
1.11 & $4.62 \mathrm{E}-02$ & $1.71 \mathrm{E}-03$ \\
0.01 & $2.93 \mathrm{E}-04$ & $1.08 \mathrm{E}-05$ \\
0.11 & $4.41 \mathrm{E}-03$ & $1.63 \mathrm{E}-04$ \\
0.08 & $3.49 \mathrm{E}-03$ & $1.29 \mathrm{E}-04$ \\
0.28 & $1.15 \mathrm{E}-02$ & $4.26 \mathrm{E}-04$
\end{tabular}

curies/s curies/s

8.64E-10 3.20E-11

1.18E-06 4.37E-08

$1.03 \mathrm{E}-08 \quad 3.82 \mathrm{E}-10$

$1.67 \mathrm{E}-08 \quad 6.18 \mathrm{E}-10$

6.04E-11 2.23E-12

2.11E-10 7.81E-12

1.21E-06 4.50E-08

2.06E-09 7.65E-11 
Table 10. Meteorological and Burning Heat Release Conditions

$\begin{array}{llll}\begin{array}{l}\text { Total Mass } \\ \text { Combusted } \\ \text { metric ton }\end{array} & \begin{array}{l}\text { Moisture } \\ \text { Content }\end{array} & \begin{array}{l}\text { Heat of } \\ \text { Combustion }\end{array} & \begin{array}{l}\text { Height } \\ \text { Plume } \\ \text { Rise } \\ \text { meters }\end{array} \\ 17.5 & 0.5 & 75617 & 24\end{array}$

X/Q for Meteorological and Burning Heat Release Conditions

Case Distance

Initial Phase

Stability Class

Mixing Depth

B Wind Speed $5 \mathrm{~m} / \mathrm{s}$

$\begin{array}{rrrr}2000 \mathrm{~m} & & \text { Crit-Sig Z* } & 940 \mathrm{~m} \\ & & & \\ 19.6 & 152.0 & 404.1 & 1180.0 \\ 10.2 & 49.0 & 129.4 & 374.6 \\ 6.53 \mathrm{E}-07 & 6.54 \mathrm{E}-06 & 1.17 \mathrm{E}-06 & 1.43 \mathrm{E}-07\end{array}$

Final Phase

Stability Class

Mixing Depth, m

D Wind Speed $2 \mathrm{~m} / \mathrm{s}$

Sig-Y

Sig-Z

$\mathrm{X} / \mathrm{Q}$

$$
200 \mathrm{~m}
$$

Crit-Sig Z

$94 \mathrm{~m}$

Sig-Y

Sig-Z

9.3

72.5

192.8

563.0

5.0

23.9

63.0

182.3

$\mathrm{X} / \mathrm{Q}$

3.43E-03

9.19E-05

1.31E-05

3.76E-06

* $\sigma_{z}$ at which the vertical spread of the plume is strongly influenced by the height of the mixed layer. 
Table 11. Air Concentration, Initial Stage, Wind Speed $5 \mathrm{~m} / \mathrm{s}$

\begin{tabular}{|c|c|c|c|c|c|c|}
\hline \multirow[b]{2}{*}{ Element $(1 \mathrm{~g} / \mathrm{m} 3)$} & \multirow[b]{2}{*}{0.1} & \multicolumn{3}{|c|}{ Distance (km) } & \multicolumn{2}{|l|}{ SC } \\
\hline & & 1 & 3 & 10 & TWA* & AAOS* \\
\hline Aluminum & $3.92 E+00$ & $2.70 \mathrm{E}-01$ & $3.99 \mathrm{E}-02$ & $4 . \overline{75 E}-03$ & 2000 & \\
\hline Arsenic & $7.50 \mathrm{E}-01$ & 5.18E-02 & $7.65 \mathrm{E}-03$ & $9.10 \mathrm{E}-04$ & 200 & 230 \\
\hline Barium & $1.50 \mathrm{E}-01$ & $1.03 E-02$ & $1.53 \mathrm{E}-03$ & $1.82 \mathrm{E}-04$ & 500 & \\
\hline Cadmium & $4.56 \mathrm{E}-01$ & $3.15 \mathrm{E}-02$ & $4.66 \mathrm{E}-03$ & $5.54 \mathrm{E}-04$ & 10 & 560 \\
\hline Chromium & $1.16 \mathrm{E}-01$ & 8.02E-03 & $1.18 \mathrm{E}-03$ & $1.41 \mathrm{E}-04$ & 50 & 83 \\
\hline Copper & $7.66 \mathrm{E}-01$ & $5.29 \mathrm{E}-02$ & $7.82 \mathrm{E}-03$ & 9.30E-04 & 100 & \\
\hline Lead & $1.13 \mathrm{E}-01$ & $7.85 \mathrm{E}-03$ & $1.16 \mathrm{E}-03$ & $1.38 \mathrm{E}-04$ & 150 & 500 \\
\hline Manganese & $5.17 \mathrm{E}+00$ & 3.57E-01 & 5.28E-02 & $6.28 \mathrm{E}-03$ & 1000 & \\
\hline Magnesium & $5.49 E+00$ & 3.79E-01 & 5.60E-02 & $6.66 \mathrm{E}-03$ & 10000 & \\
\hline Mercury & $3.48 \mathrm{E}-02$ & $2.40 \mathrm{E}-03$ & 3.55E-04 & 4.23E-05 & 50 & \\
\hline Nickel & 5.23E-01 & 3.61E-02 & 5.33E-03 & $6.35 \mathrm{E}-04$ & 50 & 80 \\
\hline Silver & 4.14E-01 & $2.86 \mathrm{E}-02$ & 4.23E-03 & 5.03E-04 & 10 & 3300 \\
\hline Zinc & $1.36 \mathrm{E}+00$ & $9.41 E-02$ & $1.39 \mathrm{E}-02$ & $1.65 \mathrm{E}-03$ & 5000 & \\
\hline
\end{tabular}

Radionuclide (pCi/m3)

\begin{tabular}{|c|c|c|c|c|c|c|}
\hline & & & & & 1 mrem* & 100 mrem* \\
\hline Americium-241 & $1.02 \mathrm{E}-01$ & $7.08 \mathrm{E}-03$ & $1.04 \mathrm{E}-03$ & $1.24 \mathrm{E}-04$ & 2.81E-01 & $2.81 \mathrm{E}+01$ \\
\hline Cesium-137 & $1.39 \mathrm{E}+02$ & $9.66 \mathrm{E}+00$ & $1.42 \mathrm{E}+00$ & $1.69 E-01$ & $4.56 \mathrm{E}+03$ & $4.56 \mathrm{E}+05$ \\
\hline Cobalt- 60 & $1.22 \mathrm{E}+00$ & $8.45 \mathrm{E}-02$ & $1.24 \mathrm{E}-02$ & $1.48 \mathrm{E}-03$ & $4.87 \mathrm{E}+03$ & $4.87 \mathrm{E}+05$ \\
\hline Curium-243,244 & 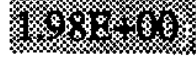 & (1) - & 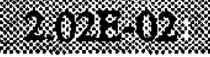 & 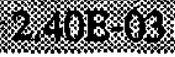 & 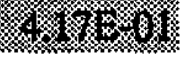 & 4.17E+01 \\
\hline Plutonium-238 & $7.16 \mathrm{E}-03$ & $4.94 \mathrm{E}-04$ & $7.30 \mathrm{E}-05$ & 8.69E-06 & 3.17E-01 & $3.17 \mathrm{E}+01$ \\
\hline Plutonium-239,240 & $2.50 \mathrm{E}-02$ & $1.72 \mathrm{E}-03$ & 2.55E-04 & $3.03 E-05$ & $2.86 \mathrm{E}-01$ & $2.86 \mathrm{E}+01$ \\
\hline Strontium-90 & $1.44 \mathrm{E}+02$ & $9.96 \mathrm{E}+00$ & $1.47 \mathrm{E}+00$ & $1.75 \mathrm{E}-01$ & $6.35 \mathrm{E}+02$ & $6.35 E+04$ \\
\hline Uranium-238 & 2.45E-01 & $1.69 \mathrm{E}-02$ & $2.50 \mathrm{E}-03$ & 2.97E-04 & $6.08 E+01$ & $6.08 \mathrm{E}+03$ \\
\hline
\end{tabular}

* The measured concentrations are compared to concentrations based on standards for each element and radionuclide. The guides for elemental concentrations are the 8-hour time weighted average limit set in CFR29, part 1910 (TWA) and the South Carolina Ambient Air Quality Standards (AAQS). Radionuclide concentrations are based on inhalation doses of $1 \mathrm{mrem}$, the NCRP guide for negligible health effects, and 100 mrem, the DOE guide for annual exposure.

Shaded areas denote that the calculated air concentration at one of the reference distances is greater than one of the standards. 
Table 12. Air Concentration, Final Stage, Wind Speed $2 \mathrm{~m} / \mathrm{s}$

\begin{tabular}{|c|c|c|c|c|c|c|}
\hline \multirow[b]{2}{*}{ Element (ug/m3) } & \multicolumn{4}{|c|}{ Distance (km) } & \\
\hline & 0.1 & 1 & $\mathbf{3}$ & 10 & TWA* & AAOS* \\
\hline Aluminum & $4.20 \mathrm{E}+00$ & $1 . \overline{12 E}-01$ & $1.60 \mathrm{E}-02$ & $4 . \overline{1 E}-03$ & 2000 & \\
\hline Arsenic & 8.05E-01 & $2.15 \mathrm{E}-02$ & 3.07E-03 & 8.83E-04 & 200 & 230 \\
\hline Barium & $1.61 E-01$ & 4.31E-03 & $6.14 \mathrm{E}-04$ & $1.76 \mathrm{E}-04$ & 500 & \\
\hline Cadmium & $4.90 \mathrm{E}-01$ & $1.31 \mathrm{E}-02$ & $1.86 \mathrm{E}-03$ & 5.37E-04 & 10 & 560 \\
\hline Chromium & $1.24 \mathrm{E}-01$ & 3.34E-03 & 4.75E-04 & $1.36 \mathrm{E}-04$ & 50 & 83 \\
\hline Copper & 8.23E-01 & $2.20 \mathrm{E}-02$ & 3.13E-03 & $9.02 \mathrm{E}-04$ & 100 & \\
\hline Lead & $1.22 \mathrm{E}-01$ & $3.27 \mathrm{E}-03$ & 4.65E-04 & $1.34 \mathrm{E}-04$ & 150 & 500 \\
\hline Manganese & $5.55 \mathrm{E}+00$ & $1.48 E-01$ & $2.11 \mathrm{E}-02$ & $6.09 \mathrm{E}-03$ & 1000 & \\
\hline Magnesium & $5.89 E+00$ & $1.57 \mathrm{E}-01$ & $2.24 \mathrm{E}-02$ & $6.46 \mathrm{E}-03$ & 10000 & \\
\hline Mercury & $3.74 \mathrm{E}-02$ & $1.00 \mathrm{E}-03$ & $1.42 \mathrm{E}-04$ & 4.10E-05 & 50 & \\
\hline Nickel & 5.62E-01 & $1.50 \mathrm{E}-02$ & $2.14 \mathrm{E}-03$ & $6.16 \mathrm{E}-04$ & 50 & 80 \\
\hline Silver & 4.45E-01 & $1.19 \mathrm{E}-02$ & $1.69 \mathrm{E}-03$ & $4.88 \mathrm{E}-04$ & 10 & 3300 \\
\hline Zinc & $1.46 \mathrm{E}+00$ & 3.91E-02 & 5.58E-03 & $1.60 \mathrm{E}-03$ & 5000 & \\
\hline
\end{tabular}

Radionuclide (pCi/m3)

\begin{tabular}{|c|c|c|c|c|c|c|}
\hline & & & & & 1 mrem* & 100mrem* \\
\hline 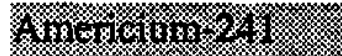 & 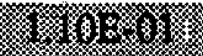 & 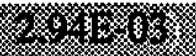 & 4 . & (1) & 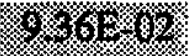 & $9.36 \mathrm{E}+00$ \\
\hline Cesium-137 & $1.50 \mathrm{E}+02$ & $4.02 \mathrm{E}+00$ & $5.72 \mathrm{E}-01$ & $1.64 \mathrm{E}-01$ & $1.52 \mathrm{E}+03$ & $1.52 E+05$ \\
\hline Cobalt -60 & $1.31 \mathrm{E}+00$ & $3.51 \mathrm{E}-02$ & $5.00 \mathrm{E}-03$ & $1.44 \mathrm{E}-03$ & $1.62 \mathrm{E}+03$ & $1.62 E+05$ \\
\hline 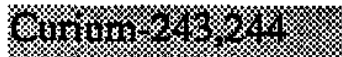 & 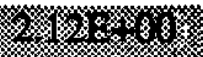 & - & 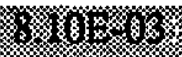 & 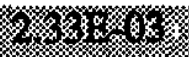 & (x) & $1.39 E+01$ \\
\hline Plutonium-238 & $7.69 \mathrm{E}-03$ & & & $8.43 E-06$ & $1.05 \mathrm{E}-01$ & $1.05 \mathrm{E}+01$ \\
\hline $\mathrm{m}-239,240$ & $2.68 \mathrm{E}-02$ & 7.19E-04 & 1.02E-04 & 2.94E-05 & $9.54 \mathrm{E}-02$ & $9.54 \mathrm{E}+00$ \\
\hline um-90 & $1.55 \mathrm{E}+02$ & $4.14 E+00$ & $5.90 \mathrm{E}-01$ & 1.69 & $2.11 E+02$ & $2.11 \mathrm{E}+04$ \\
\hline Uranium-238 & 2.63E-01 & $7.04 \mathrm{E}-03$ & $1.00 \mathrm{E}-03$ & $2.88 \mathrm{E}-04$ & $2.02 \mathrm{E}+01$ & $2.02 E+03$ \\
\hline
\end{tabular}

* The measured concentrations are compared to concentrations based on standards for each element and radionuclide. The guides for elemental concentrations are the 8-hour time weighted average limit set in CFR29, part 1910 (TWA) and the South Carolina Ambient Air Quality Standards (AAQS). Radionuclide concentrations are based on inhalation doses of $1 \mathrm{mrem}$, the NCRP guide for negligible health effects, and 100 mrem, the DOE guide for annual exposure.

Shaded areas denote that the calculated air concentration at one of the reference distances is greater than one of the standards. 
Table 13. Air Concentration, Initial Stage, Wind Speed $5 \mathrm{~m} / \mathrm{s}$, Basin 4 Only.

\begin{tabular}{|c|c|c|c|c|c|c|}
\hline \multirow[b]{2}{*}{ Element (ug/m3) } & \multicolumn{5}{|c|}{ Distance (km) } & \multirow{2}{*}{$\begin{array}{r}\mathbf{S C} \\
\mathrm{AAOS}^{*}\end{array}$} \\
\hline & 0.1 & 1 & $\underline{3}$ & 10 & TWA* & \\
\hline Aluminum & $3.8 \bar{E}+00$ & $1.77 \mathrm{E}-01$ & $2.58 \mathrm{E}-02$ & $3.06 \mathrm{E}-03$ & 2000 & \\
\hline Arsenic & $8.48 \mathrm{E}-01$ & $3.90 \mathrm{E}-02$ & $5.68 \mathrm{E}-03$ & $6.74 \mathrm{E}-04$ & 200 & 230 \\
\hline Barium & $6.55 \mathrm{E}-02$ & $3.01 \mathrm{E}-03$ & $4.39 \mathrm{E}-04$ & $5.21 \mathrm{E}-05$ & 500 & \\
\hline Cadmium & $9.96 \mathrm{E}-02$ & $4.58 \mathrm{E}-03$ & 6.67E-04 & 7.91E-05 & 10 & 560 \\
\hline Chromium & $5.09 \mathrm{E}-02$ & $2.34 \mathrm{E}-03$ & $3.41 \mathrm{E}-04$ & 4.05E-05 & 50 & 83 \\
\hline Copper & $2.54 \mathrm{E}-01$ & $1.17 \mathrm{E}-02$ & $1.70 \mathrm{E}-03$ & 2.01E-04 & 100 & \\
\hline Lead & $2.03 \mathrm{E}-02$ & $9.36 \mathrm{E}-04$ & $1.36 \mathrm{E}-04$ & $1.61 \mathrm{E}-05$ & 150 & 500 \\
\hline Manganese & $2.04 \mathrm{E}+00$ & $9.40 \mathrm{E}-02$ & $1.36 \mathrm{E}-02$ & $1.62 \mathrm{E}-03$ & 1000 & \\
\hline Magnesium & 8.88E-01 & 4.09E-02 & $5.94 \mathrm{E}-03$ & $7.06 \mathrm{E}-04$ & 10000 & \\
\hline Mercury & $1.99 \mathrm{E}-03$ & 9.17E-05 & $1.33 E-05$ & $1.58 \mathrm{E}-06$ & 50 & \\
\hline Nickel & $1.12 \mathrm{E}-01$ & $5.19 \mathrm{E}-03$ & $7.56 \mathrm{E}-04$ & 8.97E-05 & 50 & 80 \\
\hline Silver & $2.49 \mathrm{E}-02$ & $1.14 \mathrm{E}-03$ & $1.66 \mathrm{E}-04$ & $1.98 \mathrm{E}-05$ & 10 & 3300 \\
\hline Zinc & $5.85 \mathrm{E}-01$ & 2.69E-02 & $3.92 \mathrm{E}-03$ & 4.65E-04 & 5000 & \\
\hline
\end{tabular}

\section{Radionuclide (pCi/m3)}

$\begin{array}{lrlllll}\text { Americium-241 } & 2.96 \mathrm{E}-02 & 1.36 \mathrm{E}-03 & 1.98 \mathrm{E}-04 & 2.35 \mathrm{E}-05 & \frac{1 \mathrm{mrem} *}{2.81 \mathrm{E}-01} & \frac{100 \mathrm{mrem}^{*}}{2.81 \mathrm{E}+01} \\ \text { Cesium-137 } & 3.93 \mathrm{E}+01 & 1.81 \mathrm{E}+00 & 2.63 \mathrm{E}-01 & 3.12 \mathrm{E}-02 & 4.56 \mathrm{E}+03 & 4.56 \mathrm{E}+05 \\ \text { Cobalt-60 } & 1.53 \mathrm{E}-01 & 7.07 \mathrm{E}-03 & 1.02 \mathrm{E}-03 & 1.22 \mathrm{E}-04 & 4.87 \mathrm{E}+03 & 4.87 \mathrm{E}+05 \\ \text { Curium-243,244 } & 3.83 \mathrm{E}-01 & 1.76 \mathrm{E}-02 & 2.56 \mathrm{E}-03 & 3.04 \mathrm{E}-04 & 4.17 \mathrm{E}-01 & 4.17 \mathrm{E}+01 \\ \text { Plutonium-238 } & 3.77 \mathrm{E}-04 & 1.73 \mathrm{E}-05 & 2.53 \mathrm{E}-06 & 3.00 \mathrm{E}-07 & 3.17 \mathrm{E}-01 & 3.17 \mathrm{E}+01 \\ \text { Plutonium-239,240 } & 3.31 \mathrm{E}-04 & 1.52 \mathrm{E}-05 & 2.21 \mathrm{E}-06 & 2.63 \mathrm{E}-07 & 2.86 \mathrm{E}-01 & 2.86 \mathrm{E}+01 \\ \text { Strontium-90 } & 1.42 \mathrm{E}+01 & 6.55 \mathrm{E}-01 & 9.54 \mathrm{E}-02 & 1.13 \mathrm{E}-02 & 6.35 \mathrm{E}+02 & 6.35 \mathrm{E}+04 \\ \text { Uranium-238 } & 6.27 \mathrm{E}-02 & 2.89 \mathrm{E}-03 & 4.20 \mathrm{E}-04 & 4.98 \mathrm{E}-05 & 6.08 \mathrm{E}+01 & 6.08 \mathrm{E}+03\end{array}$

\footnotetext{
* The measured concentrations are compared to concentrations based on standards for each element and radionuclide. The guides for elemental concentrations are the 8-hour time weighted average limit set in CFR29, part 1910 (TWA) and the South Carolina Ambient Air Quality Standards (AAQS). Radionuclide concentrations are based on inhalation doses of $1 \mathrm{mrem}$, the NCRP guide for negligible health effects, and $100 \mathrm{mrem}$, the DOE guide for annual exposure.
} 
Table 14. Air Concentration, Final Stage, Wind Speed $2 \mathrm{~m} / \mathrm{s}$, Basin 4 Only.

Distance (km)

$\begin{array}{lccccrr}\text { Element (ug/m3) } & \mathbf{0 . 1} & \mathbf{1} & \mathbf{3} & \underline{10} & \text { TWA* } & \text { AAOS* } \\ \text { Aluminum } & 2.70 \mathrm{E}+00 & 7.24 \mathrm{E}-02 & 1.03 \mathrm{E}-02 & 2.96 \mathrm{E}-03 & 2000 & \\ \text { Arsenic } & 5.96 \mathrm{E}-01 & 1.59 \mathrm{E}-02 & 2.27 \mathrm{E}-03 & 6.54 \mathrm{E}-04 & 200 & 230 \\ \text { Barium } & 4.61 \mathrm{E}-02 & 1.23 \mathrm{E}-03 & 1.75 \mathrm{E}-04 & 5.05 \mathrm{E}-05 & 500 & \\ \text { Cadmium } & 7.00 \mathrm{E}-02 & 1.87 \mathrm{E}-03 & 2.67 \mathrm{E}-04 & 7.67 \mathrm{E}-05 & 10 & 560 \\ \text { Chromium } & 3.58 \mathrm{E}-02 & 9.58 \mathrm{E}-04 & 1.36 \mathrm{E}-04 & 3.92 \mathrm{E}-05 & 50 & 83 \\ \text { Copper } & 1.78 \mathrm{E}-01 & 4.77 \mathrm{E}-03 & 6.80 \mathrm{E}-04 & 1.95 \mathrm{E}-04 & 100 & \\ \text { Lead } & 1.43 \mathrm{E}-02 & 3.82 \mathrm{E}-04 & 5.45 \mathrm{E}-05 & 1.56 \mathrm{E}-05 & 150 & 500 \\ \text { Manganese } & 1.43 \mathrm{E}+00 & 3.84 \mathrm{E}-02 & 5.47 \mathrm{E}-03 & 1.57 \mathrm{E}-03 & 1000 & \\ \text { Magnesium } & 6.24 \mathrm{E}-01 & 1.67 \mathrm{E}-02 & 2.38 \mathrm{E}-03 & 6.84 \mathrm{E}-04 & 10000 & \\ \text { Mercury } & 1.40 \mathrm{E}-03 & 3.74 \mathrm{E}-05 & 5.33 \mathrm{E}-06 & 1.53 \mathrm{E}-06 & 50 & \\ \text { Nickel } & 7.93 \mathrm{E}-02 & 2.12 \mathrm{E}-03 & 3.02 \mathrm{E}-04 & 8.70 \mathrm{E}-05 & 50 & 80 \\ \text { Silver } & 1.75 \mathrm{E}-02 & 4.68 \mathrm{E}-04 & 6.67 \mathrm{E}-05 & 1.92 \mathrm{E}-05 & 10 & 3300 \\ \text { Zinc } & 4.11 \mathrm{E}-01 & 1.10 \mathrm{E}-02 & 1.56 \mathrm{E}-03 & 4.51 \mathrm{E}-04 & 5000 & \end{array}$

Radionuclide (pCi/m3)

\begin{tabular}{|c|c|c|c|c|c|c|}
\hline & & & & & 1 mrem* & $100 \mathrm{mrem} *$ \\
\hline Americium-241 & $2.08 \mathrm{E}-02$ & 5.57E-04 & $7.94 \mathrm{E}-05$ & $2.28 \mathrm{E}-05$ & $9.36 \mathrm{E}-02$ & $9.36 \mathrm{E}+00$ \\
\hline Cesium-137 & $2.76 \mathrm{E}+01$ & $7.40 \mathrm{E}-01$ & $1.05 \mathrm{E}-01$ & $3.03 E-02$ & $1.52 \mathrm{E}+03$ & $1.52 \mathrm{E}+05$ \\
\hline Cobalt -60 & $1.08 \mathrm{E}-01$ & 2.88E-03 & 4.11E-04 & $1.18 \mathrm{E}-04$ & $1.62 \mathrm{E}+03$ & $1.62 \mathrm{E}+05$ \\
\hline Curium-243,244 & 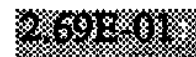 & 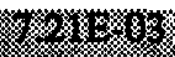 & 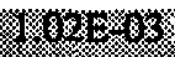 & 4) & 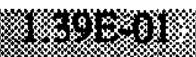 & $1.39 \mathrm{E}+01$ \\
\hline Plutonium-238 & 2.65E-04 & $7.10 \mathrm{E}-06$ & $1.01 \mathrm{E}-06$ & $2.91 \mathrm{E}-07$ & $1.05 E-01$ & $1.05 \mathrm{E}+01$ \\
\hline Plutonium-239,240 & $2.32 E-04$ & $6.23 E-06$ & 8.87E-07 & $2.55 \mathrm{E}-07$ & $9.54 \mathrm{E}-02$ & $9.54 \mathrm{E}+00$ \\
\hline Strontium-90 & $1.00 \mathrm{E}+01$ & $2.68 \mathrm{E}-01$ & $3.81 \mathrm{E}-02$ & $1.09 \mathrm{E}-02$ & $2.11 \mathrm{E}+02$ & $2.11 \mathrm{E}+04$ \\
\hline Uranium-238 & 4.41E-02 & $1.18 \mathrm{E}-03$ & $1.68 \mathrm{E}-04$ & 4.83E-05 & $2.02 E+01$ & $2.02 \mathrm{E}+03$ \\
\hline
\end{tabular}

* The measured concentrations are compared to concentrations based on standards for each element and radionuclide. The guides for elemental concentrations are the 8-hour time weighted average limit set in CFR29, part 1910 (TWA) and the South Carolina Ambient Air Quality Standards (AAQS). Radionuclide concentrations are based on inhalation doses of 1 mrem, the NCRP guide for negligible health effects, and 100 mrem, the DOE guide for annual exposure.

Shaded areas denote that the calculated air concentration at one of the reference distances is greater than one of the standards. 
Table 15. Inhalation Dose from Burning Vegetation (mrem)

\begin{tabular}{lrrrr} 
& & & \multicolumn{2}{c}{ Basin 4 Only } \\
\cline { 5 - 5 } & Day & Night & Day & Night \\
Americium-241 & 0.365 & 1.176 & 0.105 & 0.223 \\
Cesium-137 & 0.031 & 0.099 & 0.009 & 0.018 \\
Cobalt-60 & 0.000 & 0.001 & 0.000 & 0.000 \\
Curium-243,244 & 4.746 & 15.287 & 0.919 & 1.938 \\
Plutonium-238 & 0.023 & 0.073 & 0.001 & 0.003 \\
Plutonium-239,240 & 0.087 & 0.281 & 0.001 & 0.002 \\
Strontium-90 & 0.227 & 0.732 & 0.022 & 0.047 \\
Uranium-238 & $\underline{0.004}$ & $\underline{0.013}$ & 0.001 & 0.002 \\
& & & & \\
Totals & 5.483 & 17.662 & 1.059 & 2.233 \\
Total Day and Night & & 23.145 & & 3.292
\end{tabular}

